\title{
LEAF ANATOMY OF THREE HERBACEOUS BAMBOO SPECIES
}

\author{
VIEIRA, R. C., ${ }^{1}$ GOMES, D. M. S., ${ }^{2}$ SARAHYBA, L. S. ${ }^{3}$ and ARRUDA, R. C. O. \\ ${ }^{1}$ Departamento de Botânica, Instituto de Biologia, Universidade Federal do Rio de Janeiro \\ ${ }^{2}$ Departamento de Botânica, Museu Nacional, Universidade Federal do Rio de Janeiro \\ ${ }^{3}$ IBAMA-Parque Nacional do Itatiaia/Itatiaia, Departamento de Ciências Biológicas, \\ Centro Universitário de Barra Mansa, RJ \\ ${ }^{4}$ Departamento de Ciências Naturais, Escola de Ciências Biológicas, Universidade do Rio de Janeiro \\ Correspondence to: Doria Maria Saiter Gomes, Laboratório de Anatomia Vegetal, Departamento de Botânica, \\ Museu Nacional, Universidade Federal do Rio de Janeiro, Horto Botânico, Quinta da Boa Vista, São Cristóvão, \\ Rio de Janeiro, Brazil, CEP 20940-040, e-mail: jordao@vetor.com.br \\ Received May 21, 2001 - Accepted October 8, 2001 - Distributed November 30, 2002
}

(With 27 figures)

\begin{abstract}
Fully developed leaves of Cryptochloa capillata (Swallen) Soderstrom, Raddia brasilienses Bertol and Pharus lappulaceus Aublet (Poaceae: Bambusoideae) were collected at Restinga de Jacarepiá, Environment Proctection Area of Massambaba, county of Rio de Janeiro, State of Rio de Janeiro, Brazil, and studied by optical microscope. Leaf anatomy is described in order to contribute to the Poaceae family study. Anatomic features observed in the three studied species such as: midrib with complex vascular system, mesophyll consisting of tabular lobed chlorophyllous elements and fusoid cells, vascular bundles with double sheath, epidermis made up of long cells, short cells, micro-hairs, prickles and silica bodies correspond to the "bambusoid type" of leaf anatomy.
\end{abstract}

Key words: leaf anatomy, bamboo, Poaceae.

\section{RESUMO}

\section{Anatomia foliar de três espécies de bambus herbáceos}

Folhas completamente desenvolvidas de Cryptochloa capillata (Swallen) Soderstrom, Raddia brasilienses Bertol e Pharus lappulaceus Aublet (Poaceae: Bambusoideae) foram coletadas na Restinga de Jacarepiá, Área de Proteção Ambiental de Massambaba, município do Rio de Janeiro, RJ, Brasil, e estudadas ao microscópio de luz. Aspectos anatômicos são descritos, visando contribuir para o melhor conhecimento da família Poaceae. Pôde-se concluir que os caracteres observados nas três espécies, tais como nervura com complexo sistema vascular, mesofilo formado por células tabulares, lobulados clorofilados e células fusóides, feixes vasculares com dupla bainha, epiderme constituída por células longas, células curtas, micropêlos, prickles e corpos silicosos, correspondem ao tipo bambusóide de anatomia foliar descrito por diversos autores.

Palavras-chave: anatomia foliar, bambu, Poaceae.

\section{INTRODUCTION}

The Poaceae family is one of the largest among the Angiosperm families, and represented in every phytogeographic region in the world, comprising about 10,000 species which are subordinate to approximately 651 genera (Clayton \& Renvoize, 1986).

The Poaceae family is divided into six subfamilies (Clayton \& Renvoize, 1986), among which the Bambusoideae stands out. There are three general growth habits; tall woody species, 
which are largely restricted to the monsoon tropics, broad-leaved herbaceous species, which occur in the rain forest, and herbaceous swamp species, which extend from the tropics to the temperate regions (Dahlgren et al., 1985). Both in Asia and in the American tropics, the woody bamboos are some of the most visible and typical components of the flora. Unlike the woody bamboos of the Old World, which make up real forests, the American species occur mostly in their herbaceous variety, and they are found in shoal forests and in the Atlantic Rain Forest.

The anatomy and taxonomy of this subfamily has not been greatly investigated, but recent studies (Soderstrom et al., 1987b), indicate that anatomical information can be very useful in delimiting tribes and subtribes. Under this respect, the work of Brandis (1907), Prat (1932, 1936), Page (1947), Metcalfe (1956, 1960), Calderón \& Soderstrom (1973), Soderstrom et al. (1987a) and Soderstrom \& Ellis (1988) have contributed considerable anatomical data about several Bambusoideae species. Porterfield (1937), and Amarasinghe \& Watson (1988) have studied stomata ontogenesis and the ultrastructure of micro-hairs of Poaceae, respectively, and although they do not specifically deal with the anatomy of the Bambusoideae subfamily, they supply the necessary basis for a sharper definition of the structural type of the bamboo leaf.

Considering that Cryptochloa capillata (Swallen) Soderstrom, Raddia brasiliensis Berto and Pharus lappulaceus Aublet are the only representatives of the herbaceous bamboo, which occur in the Restinga of Jacarepiá, and that not much research had been done on this subfamily, mainly in relation to anatomy, the present work aims at studying the leaf anatomy of these species. Our goal is to define more precisely and more clearly the "bambusoid type" of leaf anatomy.

\section{MATERIAL AND METHODS}

The material comes from Restinga de Jacarepiá (environment protection area), Massambaba, in the State of Rio de Janeiro. The three species occur in shoal forest areas, and while Raddia brasiliensis Bertol and Pharus lappulaceus Aublet are exposed to a higher light incidence, Cryptochloa capillata (Swallen) Soderstrom can be found in more shaded places.
For the leaf anatomy analysis, fully developed leaves were collected and fixed in ethanol $70^{\circ} \mathrm{GL}$ (Jensen, 1962). Transverse sections of the midrib at median level, as well as transverse sections of the leaf-blade in the intercostal region and in the margin were obtained. In order to complement the anatomical observations, paradermal and longitudinal sections of the leaf-blade were made. Hand-sections were performed, cleared with sodium hypochlorite, washed with water, stained with astrablau-safranin (Bukatsch, 1972) and mounted in 50\% glycerol.

For some histochemical tests hand-sections of living material, submitted to specific reagents, were used. The cuticle and the cutinized and suberized cell walls were identified by sudan IV, and the lignin by phloroglucin-acid hydrochloric (Johansen, 1940). The nature of the siliceous structures was identified by dissolution into fluorhydric acid (Jones \& Handreck, 1965). In order to observe the shape variations of these structures, spodograms were prepared from leaf fragments incinerated in a muffle furnace at $800^{\circ} \mathrm{C}$, according to the instructions of Wattiez \& Sternon (1942).

For the analysis of the epidermis in surface view, small rectangles were taken from the median third of the leaf-blade, the dissociation preceded by Jeffrey's method (Johansen, 1940) and by Shultze's method (Sass, 1951). The stomata were identified according to the classification of Metcalfe (1960).

The photomicrographs were obtained at the optical microscope Orthoplan Leitz with Orthomat photographical equipment.

\section{RESULTS}

\section{Morphology}

Cryptochloa capillata (Swallen) Soderstrom in Brittonia 34: 202 (1982).

Typus: Brazil, Langsdorff

Description - Perennial herb, cespitose; upright culms reaching up to $1.30 \mathrm{~m}$ in height, inconspicuously hairy; foliar sheaths presenting pilose margins; well developed membranaceous ligule, irregular apex; glabrous petiole about $1 \mathrm{~mm}$ long, $1 \mathrm{~mm}$ wide; elliptical blade with widened base, 4.0 to $17.0 \mathrm{~cm}$ long, 1.5 to $4.0 \mathrm{~mm}$ wide, glabrous. Terminal panicle inflorescence with separated sex spikelets, the female ones in distal position, also with the occurrence of racemose inflorescences in axillar position in unisexual spikelets, generally female ones (Fig. 1). 
Comments: The species is represented in the studied area by a small population located in Floresta Seca in the State Ecological Reserve of Jacarepiá. It belongs to the herbaceous bamboo group (Soderstrom et al., 1988), limited to the Neotropical band.

Raddia brasiliensis Bertol. in Bologn. Opusc. Sci. 3: 410. 1819

Typus: Brazil, Raddi

Description - Perennial, cespitose; upright, slightly decumbent culms, 15 to $40 \mathrm{~cm}$ high, glabrous; glabrous foliar sheaths; membranaceous, glabrous, minute ligule; glabrous pseudopetiole, about $0.8 \mathrm{~mm}$ long, $1.0 \mathrm{~mm}$ wide; oblong-lanceolate, apiculate foliar blade, 0.8 to $7.0 \mathrm{~cm}$ long, 0.3 to $2.6 \mathrm{~cm}$ wide, glabrous, asymmetrical. Unisexual inflorescences, the male spikelets in terminal or axillar panicules and the female spikelets in auxiliary racemes; ovoid - oblong caryopsis, $4.5 \mathrm{~mm}$ long, $1.6 \mathrm{~mm}$ wide, clear, glossy (Fig. 2).

Comments: The blossoming of bamboos is cyclic in most cases, occurring when they reach physiological maturity (Filgueiras, 1988). The species, as well as Pharus lappulaceus, has been seen in several forest areas in the State of Rio de Janeiro, Brazil. It presents separated sex spikelets. At sundown the blades come together, a phenomenon that is observed in several herbaceous bamboos and is described as "sleep movements" (Soderstrom \& Calderón, 1979; Soderstrom, 1980).

Pharus lappulaceus Aublet, Fl. French Guiana 2: 859. 1775.

Typus: Ill. Plumier mss. t. 5. Fig. 85.

Description - Perennial, cespitose, upright culm, sometimes slightly arched, commonly reaching up to $70 \mathrm{~cm}$ in height, glabrous; glabrous foliar sheaths; membranaceous ligule, ciliate apex; elongated pseudopetiole becoming twisted towards the blade; linear-lanceolate foliar blade, 5.0 to 24.0 $\mathrm{cm}$ long, 1.3 to $2.2 \mathrm{~cm}$ wide, secondary ribs converging towards the main rib, prominent transverse ribs. Lax panicle inflorescence in the maturing of the branches, presenting hyaline hairs all over the inflorescence branches. Spikelets in pairs, the female being well developed, and the male smaller and positioned on a long pedicel (Fig. 3).

Comments: Pharus lappulaceus participates, together with Raddia brasiliensis, of the herbaceous stratum of Floresta Seca in the State Ecological
Reserve of Jacarepiá. A species from the tropical forests, it presents an unusual rib pattern in its foliar blades. The ribs show a converging parallelism to the main rib

\section{Anatomy}

In front view, the epidermis of $C$. capillata, $R$. brasiliensis and $P$. lappulaceus consists of cells of varied shapes and sizes, organized in costal and intercostal zones (Figs. 4-16).

On the adaxial surface, the costal zones of $C$. capillata (Figs. 4-5) and R. brasiliensis (Fig. 8) are made up of alternately disposed long and short cells. The long cells have sinuous anticlinal walls, whereas the short ones can be of two kinds: siliceous and suberose. The siliceous cells present varied dimensions and shapes, occurring isolately or forming pairs with the suberose ones, whose walls present positive response to the sudan IV test. In P. lappulaceus (Figs. 12-14) the costal zones consist of lignified epidermic fibers, forming 2 to 8 ranks, among which suberose and siliceous cells are found. Such cells are alternately disposed, being the latter more numerous, characterized by the presence of a silica body in them. The intercostal zones, in $C$. capillata (Figs. 4-5) and $R$. brasiliensis (Fig. 8) are formed by up to 14 ranks of cells, whose anticlinal walls are sinuous and thickened. In this band there occur 2 to 5 cell ranks that present pale coloring by safranin. In P. lappulaceus (Figs. 12-14), the intercostal zones consist of 10 to 15 cell ranks, which vary in outline from straight to slightly sinuous, tending to a hexagonal shape. In transverse section, the elements constituting the intercostal zones of P. lappulaceus (Fig. 19), as well as the dimly colored cells of $C$. capillata and $R$. brasiliensis (Figs. 1718) correspond to the bulliform cells.

In the abaxial surface, the costal zones of $C$. capillata (Figs. 6-7) and $R$. brasiliensis (Figs. 8-11) consist of elongated cells with sinuous anticlinal walls, alternating with suberose and siliceous cells. In $P$. lappulaceus (Figs. 15-16) this zone is formed by lignified epidermic fibers, which are organized in bundles having from 3 to many elements, among which there occur suberose and siliceous cells. Besides occurring on the ribs, the fibers are regularly disposed in two-element groups all over the abaxial surface. In the intercostal zones in C. capillata (Figs. 6-7) and $R$. brasiliensis (Figs. 9-11), long epidermal cells with sinuous anticlinal walls intercalate with short siliceous and suberose ones. 


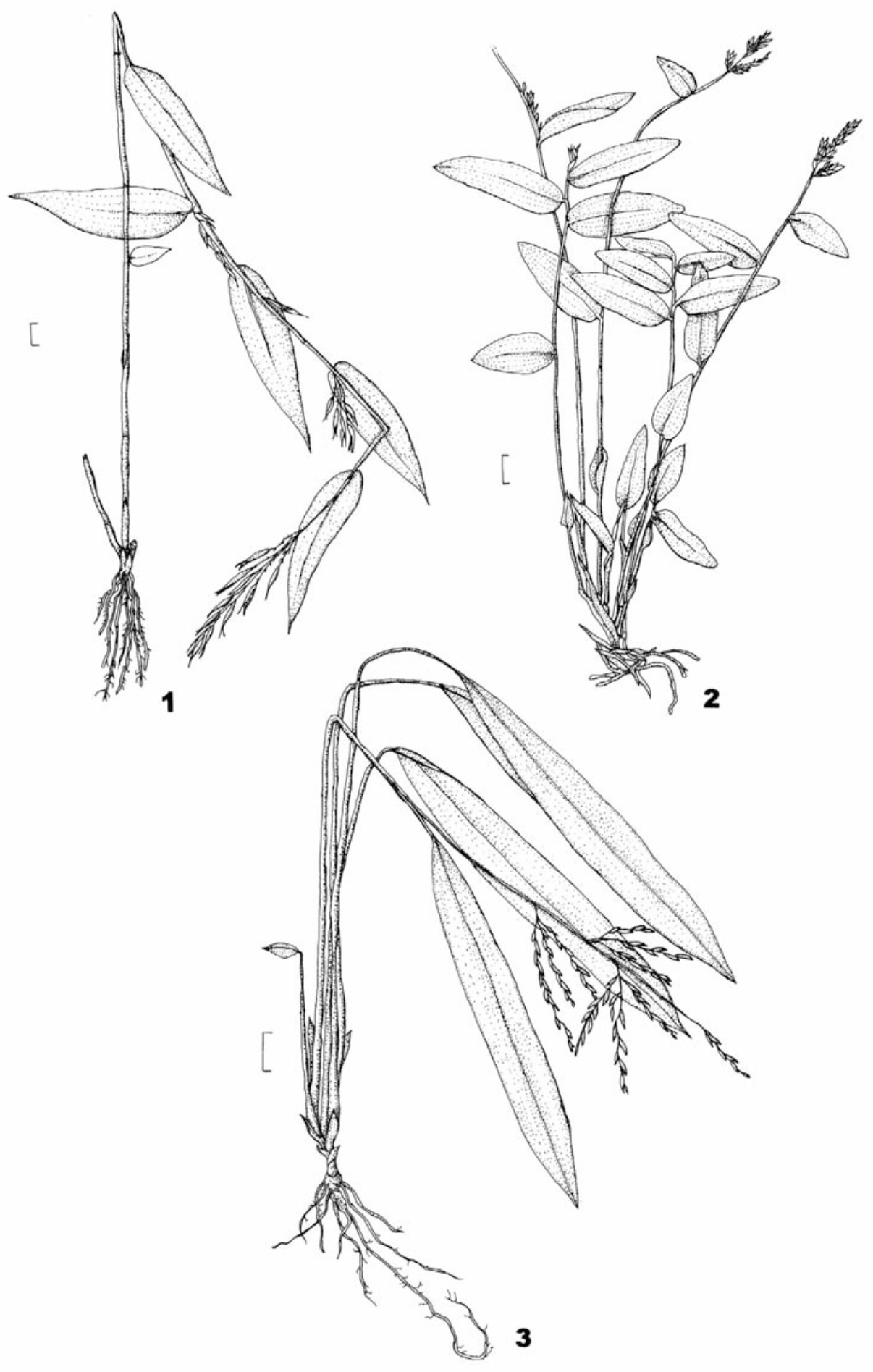

Figs. 1-3 - Habit of Cryptochloa capillata (1), Raddia brasiliensis (2) and Pharus lappulaceus (3) $(\mathrm{bar}=2 \mathrm{~cm})$.

Braz. J. Biol., 62(4B): 907-922, 2002 

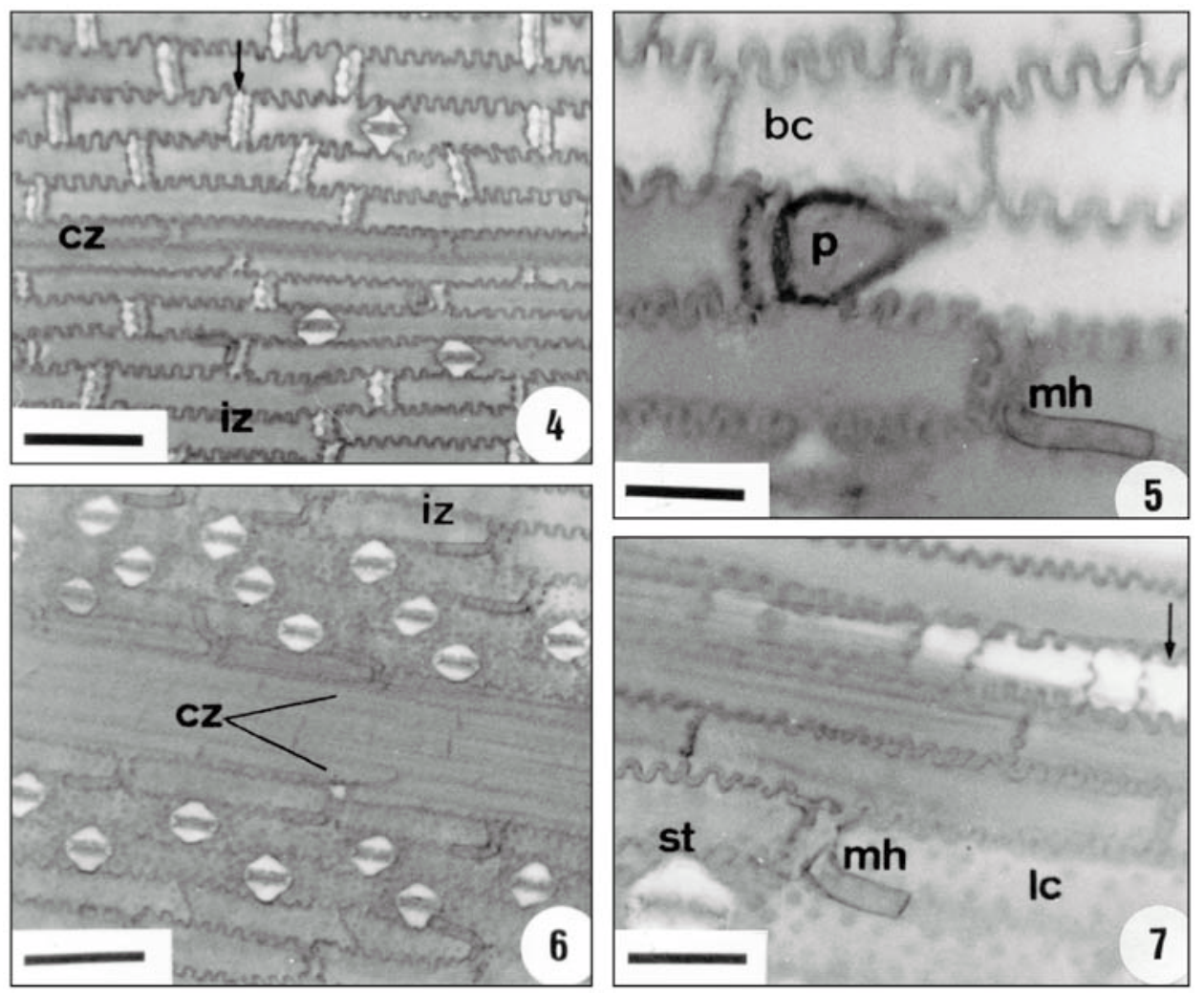

Figs. 4-7 - Leaf epidermis of C. capillata in front view. 4 - Adaxial surface showing costal zone (cz), intercostal zone (iz), suberose cells and silica bodies in pairs (arrow) (bar $=64 \mu \mathrm{m}) . \mathbf{5}$ - Adaxial surface showing bulliform cells (bc), prickles (p) and micro-hairs $(\mathrm{mh})(\mathrm{bar}=26 \mu \mathrm{m}) .6$ - Abaxial surface showing costal zone (cz) and intercostal zone (iz) with long cells with sinuous anticlinal walls, stomata and micro-hairs (bar $=67 \mu \mathrm{m}) .7-$ Detail showing cross-shaped silica bodies (arrow), stomata (st), micro-hairs $(\mathrm{mh})$ and long cells with papillae $(\mathrm{lc})(\mathrm{bar}=19 \mu \mathrm{m})$.

The presence of innumerous cuticular papillae is evident in this zone, especially in the elements lying near the costal zones, and they may also be found in the costal zones of $R$. brasiliensis (Figs. 9-10). In P. lappulaceus (Figs. 15-16) this zone is made up of long cells with sinuous anticlinal walls. Silica may be present under two forms: either impregnating the wall cells so that a reduced lumen is left, as one can observe in the abaxial surface of $R$. brasiliensis (Fig. 11), or occupying the whole cell. In this case, when isolated, it is possible to evidence the presence of a silica body, which can be of three kinds: long with a sinuous outline (Fig. 8), short and cross-shaped (Figs. 9-10), and dumb-bell-shaped (Fig. 13).
The long type with a sinuous outline can be found in the intercostal zones of $C$. capillata and $R$. brasiliensis, the short and cross shaped type occur in the costal zones of the same species, however the dumb-bell-shaped only occur in $P$. lappulaceus. Besides, it is possible to notice the silicification of some long cells of $C$. capillata and $R$. brasiliensis.

Two kinds of trichomes occur in the epidermis of the three studied species: micro-hairs and prickles. Micro-hairs consist of two cells having approximately the same size: one of them basal, and the other one apical. Such elements possess thin fragile walls, particularly the apical cell, which is often absent or, when present, is found deformed. 
In $C$. capillata micro-hairs are distributed in the intercostal zones of both surfaces (Figs. 5, 7 ), whereas in R. brasiliensis this kind of hair is observed in the intercostal zones of the abaxial surface (Fig. 9). In P. lappulaceus this kind of trichome is not observed.

Prickles are unicellular, and they are distinguished by a dilated base and a pointed apex.
They occur in the intercostal zones of the adaxial surface of $C$. capillata (Fig. 5), whereas in $R$. brasiliensis these hairs are found in the intercostal zones of both surfaces (Figs. 9-10). In $P$. lappulaceus this kind of trichome is only observed in the costal zones of the adaxial surface (Fig. 14). At times this trichome may present a silicaimpregnated wall.
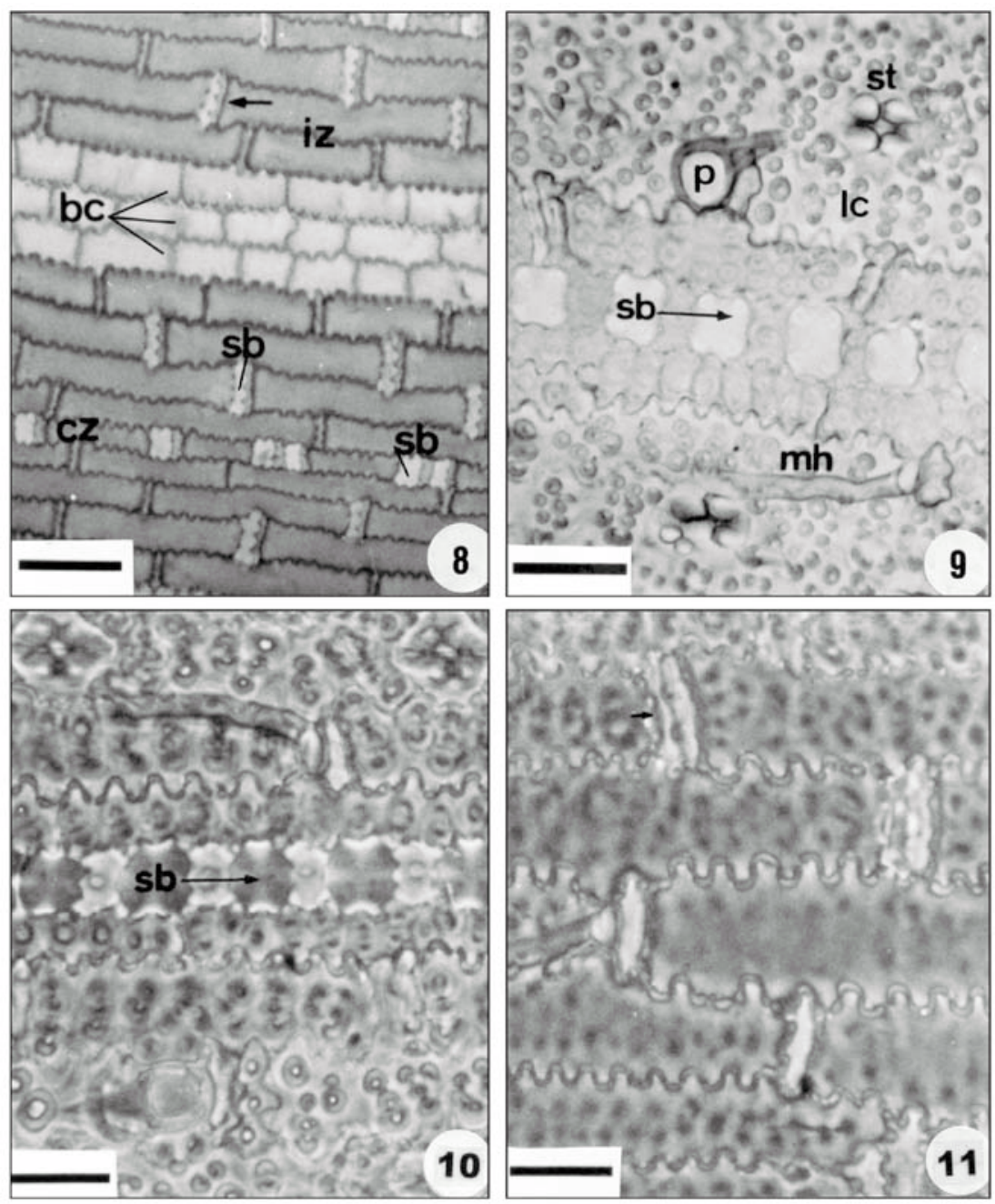

Figs. 8-11 - Leaf epidermis of $R$. brasiliensis in front view. 8 - General appearance of adaxial surface showing costal zones (cz) with cross-shaped silica bodies (sb), and intercostal zones (iz) with silica bodies with sinuous outlines (sb), suberose cells (arrow) and bulliform cells $(\mathrm{bc})(\mathrm{bar}=82 \mu \mathrm{m}) .9$ - Detail of the abaxial surface showing cross-shaped silica bodies (sb), prickles (p), micro-hairs (mh), stomata (st), and innumerous papillae per long cell (lc) $(\mathrm{bar}=30 \mu \mathrm{m}) .10$ - Cross-shaped silica bodies $(\mathrm{sb})$ in the costal zone in phase contrast $(\mathrm{bar}=25 \mu \mathrm{m})$. 11 - Short cells with silified walls in the intercostal zone (arrow) in phase contrast (bar $=25 \mu \mathrm{m}$ ). 
The leaves of the three studied species are amphistomatic, yet the number of stomata is variable when the epidermises of the two surfaces are compared. In $C$. capillata and $R$. brasiliensis stomata are organized in 4 ranks, with 2 on each side of the costal zones (Figs. 6, 9). The stomatic density is low in the adaxial surface, a greater concentration occurring in the abaxial one. In $P$. lappulaceus the stomata are distributed in a larger number and in a regular pattern in the adaxial surface, and they are organized in 2 ranks, one on each side of the fiber band, following the path of the vascular system (Fig. 12).

Fusoid cells are present on both sides of all vascular bundles, and they are distinguished by their extremely thin walls and by being achlorophyllous (Figs. 17-20). They lie perpendicular to the vascular bundles, and they may be adaxially located in P. lappulaceus (Figs. 19-20) or abaxially located in $C$. capillata and $R$. brasiliensis (Figs. 17-18). The adjacent fusoid cells are separated from one another by 1 to 5 elements of the chlorophyllous parenchyma.

The chlorophyllous parenchyma is of the plicate kind with vertically oriented invaginations and is organized in 1 to 3 strata located above the fusoid cells, and 1 to 2 strata which are abaxially located in this cells. It is noteworthy that such invaginations in $P$. lappulaceus are more evident in those elements facing the abaxial surface (Fig. 19), whereas in C. capillata (Fig. 17) and $R$. brasiliensis (Fig. 18) they can be noted in the elements belonging to the adaxial surface.

In the marginal area (Figs. 21-23) one can observe the reduction in size of the epidermal elements as well as strong sclerification of the cell walls, especially in P. lappulaceus (Fig. 23). The chlorophyllous parenchyma, as it nears the margin, displays a gradational change in size and in its invaginations, particularly in C. capillata (Fig. 21) and $R$. brasiliensis (Fig. 22), until it is replaced by lignified elements.

The vascular system consists of varied-sized collateral bundles located among fusoid cells (Figs. 17-19). A double sheath envelops the conducting tissues. The outer sheath, called endodermis, is formed by achlorophyllous parenchymatic cells and it is often found abaxially interrupted, above all in middle-sized and large-sized bundles (Fig. 19). The inner sheath, called pericycle, consists of elements of sclerenchymatic nature with a uniform wall thickening, and it can be exceptionally absent in bundles of smaller caliber. Sheath extensions of sclerenchymatic nature can be observed in all bundles, and they may reach one or both epidermes.

Of the three studied species, the transverse section of the median third of the leaf, at midrib level, shows varied shapes (Figs. 24-27). C. capillata (Figs. 24, 27) and R. brasiliensis (Fig. $25)$ posses concave-convex shape, whereas in $P$. lappulaceus (Fig. 26) the midrib shape is flatconvex. The vascular system consists of 2 or 3 bundles of the collateral type, embedded in the ground tissue. In C. capillata (Fig. 24) and $R$. brasiliensis (Fig. 25) 3 abaxially located bundles occur, the central one being the largest, and two smaller ones being on the sides. In P. lappulaceus (Fig. 26) a central larger size bundle, occurs abaxially and a smaller one occurs facing the opposite leaf surface. All the bundles are encircled by inner pericyclic fibers, which may or may not reach the epidermis and by an outer parenchymatic endodermis (Figs. 24-27). In P. lappulaceus the epidermes (Fig. 26) may appear lignified.

Although the vascular system organization may be similar all along the midrib, small variations were observed according to the level of the studied section. Thus, a larger number of bundles occur in the basal third, whereas this number is reduced in the apical third, being at times represented by one single bundle.

\section{DISCUSSION}

The analysis of the leaf structure of the three studied species has revealed characteristics, which correspond to those mentioned by Ellis (1976, 1979) and Esau (1977) for the Poaceae family.

The Poaceae epidermis, in surface view, is divided in zones or conspicuous bands. In general it is possible to distinguish two main zones: intercostal and costal zones. In the three studied species the epidermis is similarly organized, which agrees with Metcalfe's observations (1960). 

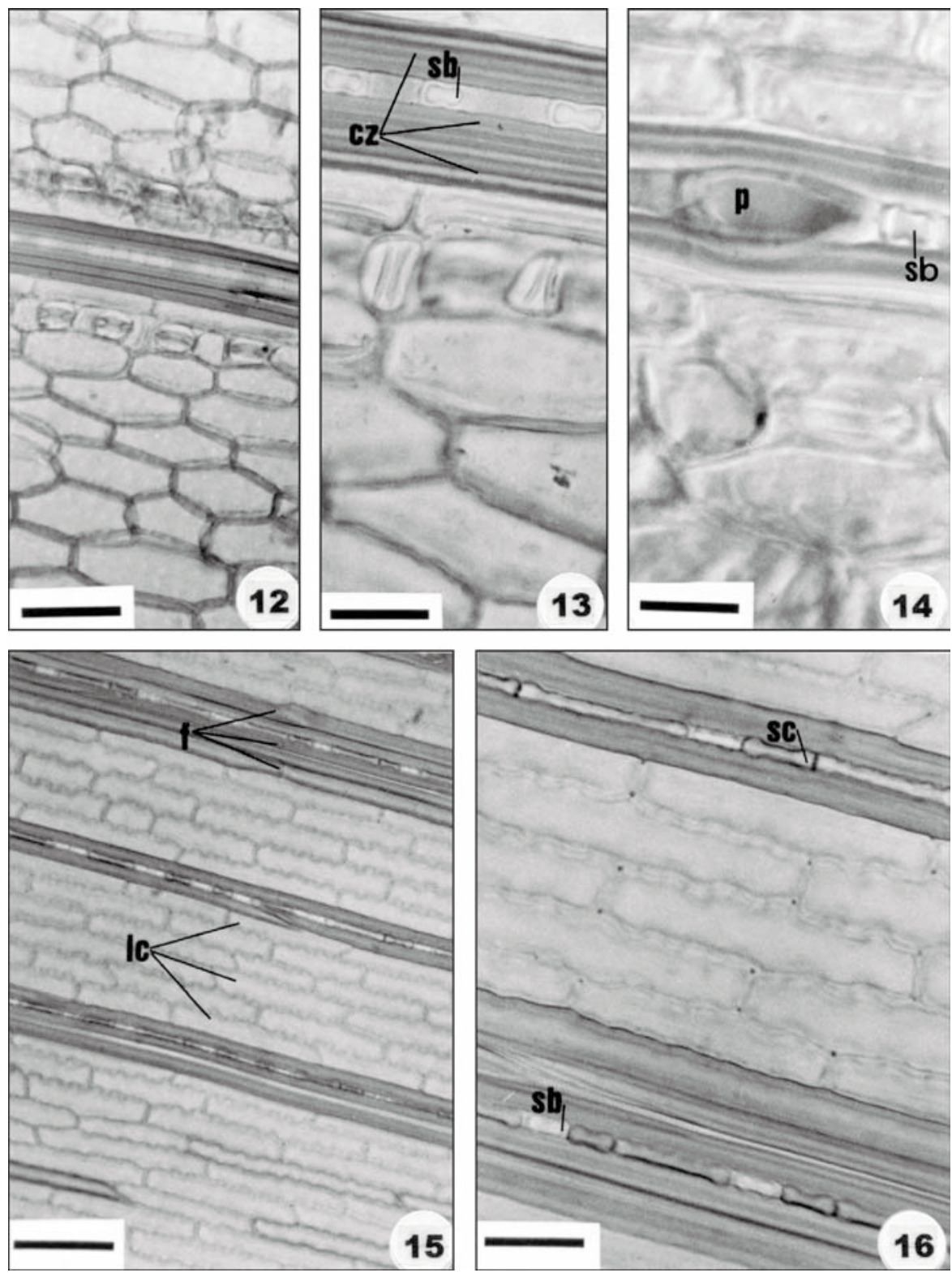

Figs. 12-16 - Leaf epidermis of P. lappulaceus in front view. 12 - General appearance of the adaxial surface showing stomata next to the epidermic fibers $(\mathrm{bar}=56 \mu \mathrm{m}) .13$ - Detail showing dumb-bell-shaped silica body $(\mathrm{sb})$ of costal zone $(\mathrm{cz})(\mathrm{bar}=$ $14 \mu \mathrm{m}) .14$ - Detail in phase contrast showing prickles (p) and dumb-bell-shaped silica body (sb) $($ bar $=23 \mu \mathrm{m}) .15-\mathrm{General}$ appearance of the abaxial face showing long cells (lc) and epidermic fibers (f) (bar $=103 \mu \mathrm{m})$. 16 - Detail showing silica bodies (sb) and suberose cells (sc) among the epidermic fibers (bar $=24 \mu \mathrm{m})$. 

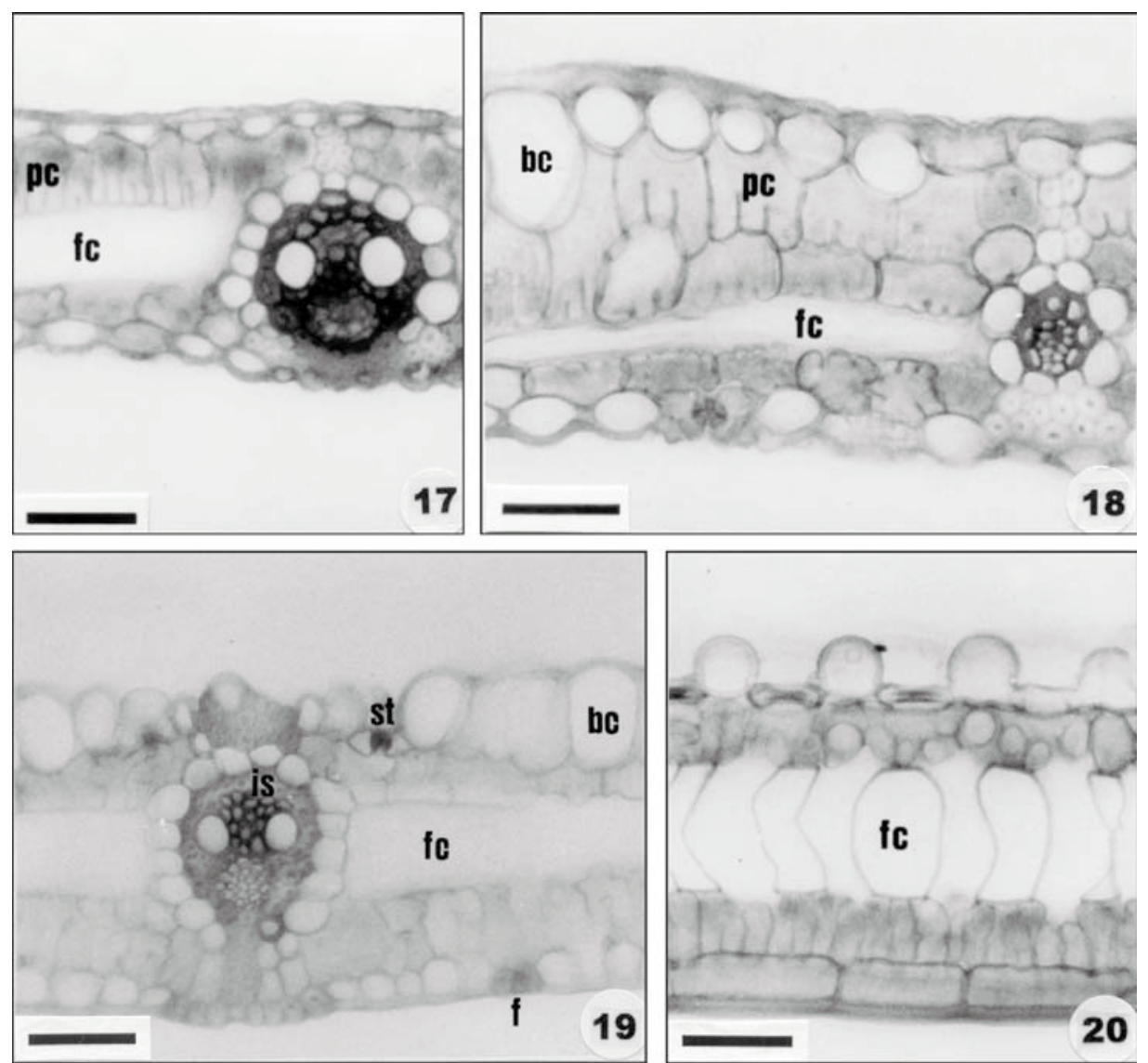

Figs. 17-20 - Transverse section (17-19) and longitudinal section (20) of leaf-blade. 17 - C. capillata showing, chlorenchyma with plicate cells (pc) and fusoid cells (fc). Notice vascular bundle with double sheath (bar $=41 \mu \mathrm{m})$. $18-R$. brasiliensis. Notice bulliform cells (bc), plicate cells (pc), fusoid cells (fc) and vascular bundle with extension of the sclerenchymatic sheath $($ bar $=25 \mu \mathrm{m}) .19-P$. lappulaceus showing regular bulliform cells (bc), stomata (st) in the adaxial surface, fusoid cells (fc), vascular bundle with lignified inner sheath (is) and epidermic fibers (f) in the abaxial surface (bar $=38 \mu \mathrm{m}$ ). $\mathbf{2 0}-$ $P$. lappulaceus showing fusoid cells (fc) $($ bar $=40 \mu \mathrm{m})$.

In general the costal and intercostal zones of the three present studied species consist of long and short cells. According to Metcalfe (1960), the shape and outline of the long cells is variable, presenting from shorter elements with non-sinuous thin walls to long elements with sinuous thickened walls. Besides, the above mentioned author states that the different kinds of long cells have been used in the solution of taxonomic problems, although he points out that this character should not be used isolatedly, since intermediate forms can be found. Thus, Soderstrom \& Ellis (1988) describe sinuous thin-walled long cells for 12 woody bamboo species while Metcalfe (1960) mentions long cells with straight, thin walls for Brachypodium sp. and Cenchus biflorus.

In the analyzed species, information obtained from Soderstrom \& Ellis (1988) is confirmed, for the long cells on both leaf surfaces possess sinuous thin walls. The short cells may occur in pairs or isolatedly, according to the studied species. They are generally classified either as siliceous cells containing one single silica body or as suberose cells. 

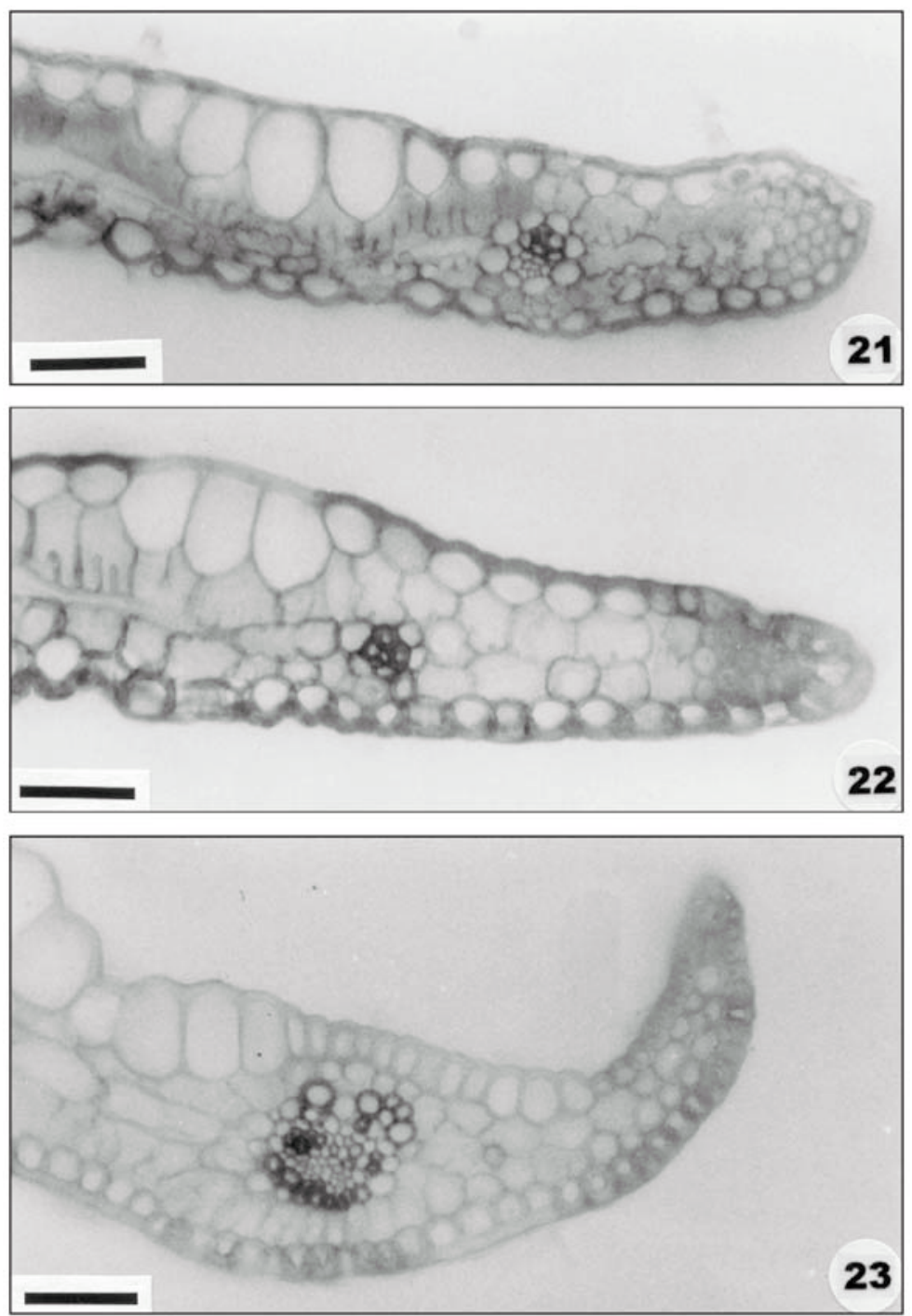

Figs. 21-23 - Transverse section of the leaf margin of C. capillata (21), R. brasiliensis (22) and P. lappulaceus (23) showing the occurrence of fibers in this region $($ bar $=40 \mu \mathrm{m})$.

Although the occurrence of siliceous or suberose cells in Poaceae is considered usual, in some species the short cell may be represented exclusively by the siliceous cell. Renvoize (1985), in a detailed study about the leaf-blade of bamboo species, mentions the occurrence of solitary or paired short cells, yet he does not mention whether suberose cells are also present.
Suberose cells are observed in the epidermis of $C$. capillata, $R$. brasiliensis and P. lappulaceus, occurring either isolatedly or forming pairs with siliceous cells, a fact that is supported by Calderón \& Soderstrom (1973) and Soderstrom \& Ellis (1988).

The presence of epidermal cells containing silica bodies is an important character in the Poaceae family (Metcalfe, 1960, 1963). 

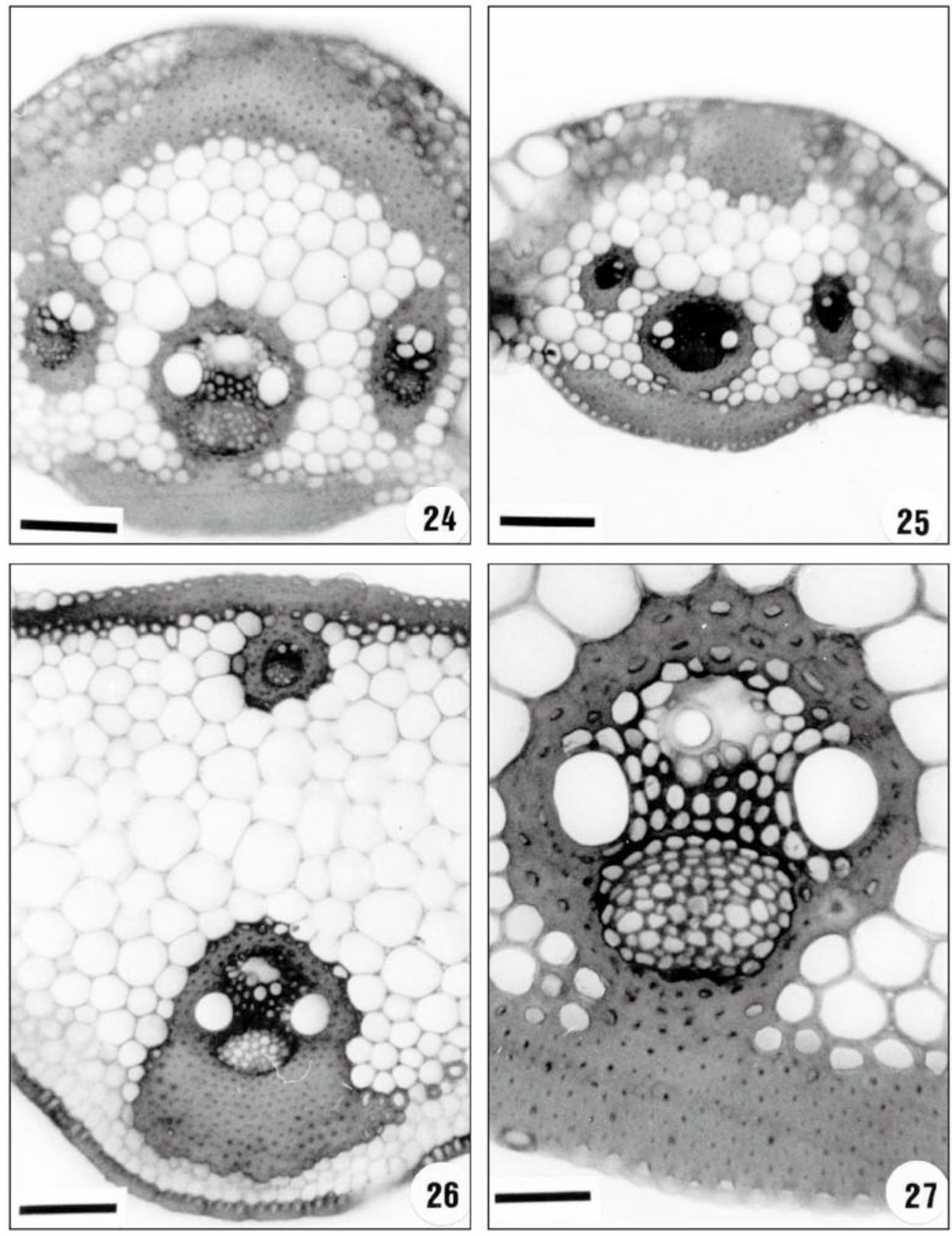

Figs. 24-27 - Transverse section of the midrib at median level. Complex vascularization consisting of 3 vascular bundles in C. capillata $(24)($ bar $=61 \mu \mathrm{m})$ and $R$. brasiliensis $(25)($ bar $=50 \mu \mathrm{m})$ and 2 vascular bundles in P. lappulaceus $(26)($ bar $=$ $60 \mu \mathrm{m}) .27$ - Detail of the main vascular bundle of $C$. capillata showing associated sclerenchyma $(\mathrm{bar}=26 \mu \mathrm{m})$. 
Metcalfe (1960) recognizes a large number of shapes these structures may present. Cavalcante (1968), Campos \& Labouriau (1969), Teixeira da Silva \& Labouriau (1970), and Söndahl \& Labouriau (1970) describe in detail the shapes that silica bodies may display in several Poaceae species. When compared, the studied species reveal variations in shape structures, since in $C$. capillata and $R$. brasiliensis there occur the horizontally elongated types with sinuous or cross-shaped outlines, whereas in P. lappulaceus only the dumbbell-shaped kind is observed.

Campos \& Labouriau (1969) mention that silica impregnation in long cells, guard cells, hairs, papillose cells and bulliform cells are quite frequent. Besides, the silification of xylem elements (Sondahl \& Labouriau, 1970) shows that this process is not confined to epidermal cells. In $C$. capillata and $R$. brasiliensis the silification of long cells is observed, and this fact denies Turpe's (1966) statement that only short cells have this property.

Although the exact physiological role of silicose deposits in leaves is not yet known, Haberlandt (1928), McNaughton \& Tarrants (1983), and Hopkins (1995) consider that silica impregnated walls prevent attacks by insects and by fungi. Campos \& Labouriau (1969) assume that silica plays an important role in hydric balance, thermic changes and radiation reflection. Besides, Lanning et al. (1958) and Moore (1984) state that silica is a complementary structural element, contributing to vegetative support.

In the Bambusoideae, three kinds of epidermal appendages, in general, occur: papillae, micro-hairs and prickles (Calderón \& Soderstrom, 1973).

Font Quer (1975) defines papillae as the simplest of trichomes, characterized by wall projection followed by the protoplast of epidermal cells. According to Ellis (1979), Poaceae papillae occur in long and short cells, especially in intercostal zones, in numbers that may vary from one to many per cell. In $C$. capillata and $R$. brasiliensis, innumerous papillae occur on the long and subsidiary cells to the abaxial surface. They are small, conical structures, resulting from a cuticular projection not being followed by the wall and protoplast of the epidermal cell. In P. lapullaceus these structures are not observed. Thus, the absence of papillae in this last mentioned species can be interpreted as a taxonomic indicator, and it may be a distinctive character of the Phareae tribe from the other ones (Renvoize, 1985). The presence of papillae seems to be an exclusive character of certain tribes among the Bambusoideae, such as Olyreae and Bambuseae (Calderón \& Soderstrom, 1973; Soderstrom \& Ellis, 1988).

Micro-hairs are commonly made up of two cells, the apical one presenting an extremely thin wall, sometimes caducous (Tateoka et al., 1959), and seem to be the most frequent kind of trichome in Bambusoideae (Prat, 1936; Calderón \& Soderstrom, 1973). C. capillata and R. brasiliensis possess bicellular micro-hairs, with thin-walled apical cells, which is mentioned by Renvoize (1985), Soderstrom \& Ellis (1988) and Paisooksantivatana \& Pohl (1992), for several groups within this sub-family. The absence of micro-hairs in representatives of the Phareae tribe has been related by several authors (Renvoize, 1985; Soderstrom et al., 1987a), which is confirmed by the results obtained in P. lappulaceus.

Prickles are easily observed in the three studied species, and they have been already mentioned by Renvoize (1985) and Soderstrom \& Ellis (1988) for Bambusoideae species.

According to Ellis (1979), the Poaceae stomata generally occur in well-defined bands in intercostal zones, and they may be classified according to the shape of subsidiary cells. Thus, in P. lappulaceus subsidiary cells are short-domeshaped whereas in $R$. brasiliensis and $C$. capillata such cells are triangular. Besides, Terrel \& Wergin (1979) state that, in Poaceae, stomata may be protected by papillae, a fact confirmed in $C$. capillata and $R$. brasiliensis.

Ellis (1976) defines bulliform cells as being an intrinsic part of the epidermis, differing from the other epidermal elements proper for being generally larger and more inflated. Besides, their occurrence and distribution may be valuable for diagnostic purposes. Shields (1951) states that during excessive water losses bulliform cells become flacid allowing the plant to bend or infold, which leads to a reduction of the leaf transpiration surface.

In the three studied species ranks of cells with ample lumen, which are weakly stained by safranin, were observed in intercostal zones of the leaf-blade adaxial surface. In $C$. capillata and $R$. brasiliensis bulliform cells are large and inflated, presented in regular groups, whereas in P. lappulaceus such elements are uniformly disposed. Soderstrom et 
al. (1987a), however, mention that in the Phareae tribe bulliform cells can be either absent or poorly developed, while Renvoize (1985) mentions the presence of bulliform cells for this tribe. Although the presence of bulliform cells in the Phareae tribe may not be very clear, the uniformly disposed elements in the adaxial surface of $P$. lappulaceus have been defined as bulliform cells.

Very often the chlorophyllous tissue found in the mesophyll of Bambusoideae is defined as being of the armform kind ("arm cells", Haberlandt, 1928; Calderón \& Soderstrom, 1973; Soderstrom \& Ellis, 1988). Prat (1936) uses the term "plicate" to describe the pleated elements of the chlorophyllous parenchyma of this sub-family. Fahn (1985) uses the term "lobed" to define the chlorophyllous parenchyma constituted by cells presenting projections on their walls. Brandis (1907) in his study of the structure of bamboo leaves describes the chlorophyllous parenchyma of these plants as being made up of cells with inward projections, which divide them into tubular compartments. Renvoize (1985), as well as Brandis (1.c.) also mentions the occurrence of these elements, yet without classifying them. In the studied species it does not seem correct to define the chlorophyllous tissue as armform, according to the suggestion of the above mentioned authors, since the cells display projections varying from lobed to plicate, thus better fitting into the lobed tabular type suggested by Freier (1959) for the Bambusoideae sub-family.

Soderstrom et al. (1987b) mention that in Bambusoideae plicate cells are usually well developed in the adaxial chlorenchyma, a fact which has been observed in $C$. capillata and $R$. brasiliensis. In P. lappulaceus, however, the welldeveloped chlorophyllous parenchyma, abaxially located, as well as the presence of stomata on the adaxial surface, is explained by a torsion suffered by the leaf-blade in the Phareae tribe; that is, the abaxial surface of the leaf is functionally adaxial.

The mesophyll of Poaceae, notedly the Bambusoideae, is marked by the presence of fusiform, colorless and thin-walled cells, frequently mistaken for intercellular spaces. Karelstschicoff (1868) seems to have been the first researcher to recognize these elements as cells. Brandis (1907) recognized these structures as cells, although he has at times mentioned them as being "apparent cavities". The cellular nature of these structures has been also confirmed by Page (1947). Metcalfe (1956) uses the term "fusoid cells" to define these elements, considering its fusiform outline when viewed in transverse section. The presence of fusoid cells in Bambusoideae is mentioned by Renvoize (1985), Soderstrom et al. (1987a, b), Soderstrom \& Ellis (1988) and Paisooksantivatana \& Pohl (1992).

Fusoid cells are present in the leaf-blade of the three studied species, confirming the proposition of Calderón \& Soderstrom (1973), who assert that the presence of these structures is an important character to define the bambusoid type of leaf anatomy.

Although the function of fusoid cells is not completely clear yet, one may suppose that these elements are related to the storing and transportation of water in the mesophyll, if we take into account their location next to vascular bundles. Besides, Clayton \& Renvoize (1986) mention that colorless thin-walled cells increase light penetration into the mesophyll interior. Futhermore, the fusoid cells by its position and characteristics could be related with the translocation end distribution of photoassimilates between the mesophyll and vascular bundles. Such hypothesis had been mentioned by Fisher (1967) and Franceschi \& Giaquinta (1983a, b, c) in their studies of the paraveinal parenchyma in Leguminosae species.

In the Poaceae leaves, the midrib may or may not present a sharp definition. With very few exceptions, the Bambusoideae possess a distinguished midrib (Brandis, 1907), which is in general adaxially projected and consists of a larger median vascular bundle, and of two smaller side bundles (Calderón $\&$ Soderstrom, 1973). In the three present studied species the midrib is conspicuous, consisting of 23 vascular bundles, adaxially projected in $C$. capillata and on both surfaces in $R$. brasiliensis. In P. lappulaceus, the midrib is abaxially projected, although it is functionally adaxial, as a result of the invertion of the pseudopetiole, agreeing with the information given by Soderstrom et al. (1987a) for the Phareae tribe.

In Poaceae, the pattern of distribution, size and organization of vascular bundles may present a wide variation, but they are generally disposed in a simple rank, approximately located in the middle of the mesophyll. Metcalfe (1960) suggests a classification for vascular bundles, describing the "basic type", characterized by the presence of 
one, or sometimes two conspicuous metaxylem vases, as being the most common among Poaceae. The vascular bundles of the three studied species belong to this type, although Calderón \& Soderstrom (1973) mention that the vascular bundles of the Bambusoideae belong to the "Leptaspis" kind of the classification by Metcalfe (1960).

In Poaceae, one or two sheaths may envelop the vascular bundles. When they are both present, the outer sheath is the endodermis, which may contain starch or chloroplasts (Carolin et al., 1973). The inner sheath, called pericycle, consists of elements presenting smaller dimensions and more thickened walls than those forming the outer sheath. The existence of outer bundle sheath, known as endodermis, has been studied by Scatena \& Nunes (1999) for Pleurothallis rupestris Lind. Silva (2000) in their research mentioned that the vascular bundles of Lagenocarpus Nees leaf are marked by a thick internal sheath, called pericycle and by an outer parenchymatic one, called endodermis, also found in the present study. Thus the inner sheath, which may be absent in many Poaceae, is always present in bamboos (Brandis, 1907; Calderón \& Soderstrom, 1973). The occurrence of double sheath is mentioned by Renvoize (1985), Soderstrom \& Ellis (1988) and Paisooksantivatana \& Pohl (1992) for several Bambusoideae species. This has been verified in the present study, since the three studied species present double sheath, the larger and smaller bundles fitting, therefore, into types 2 and 1, respectively, in Metcalfe's (1960) classification.

The supporting tissue of the Poaceae is represented by sclerenchyma, which can present several patterns of distribution, occurring in the form of sub-epidermal layers, sheath extensions, or in the leaf margin (Ellis, 1976). In the present studied species, the sclerenchyma is present and is both associated with vascular bundles and in the leaf margin, which confirms the information obtained from the above mentioned author.

Anatomical features of the leaf-blade have been recognized as valuable in the diagnosis of the six Poaceae sub-families. Thus the features observed in $C$. capillata, $R$. brasiliensis and $P$. lappulaceus such as: midrib provided with complex vascular system; mesophyll formed by invaginate chlorophyllous elements and fusoid cells; double sheath in the vascular bundles; complex epidermal tissue consisting of long and short cells, micro-hairs, prickles and silica bodies correspond to the "bambusoid type" of leaf anatomy, defined by Metcalfe (1956), Calderón \& Soderstrom (1973), Renvoize (1985) and Soderstrom et al. (1987a, b).

Acknowledgments - The authors are grateful to Dr. Nanuza Luiza de Menezes for her improvements to this paper, especially with respect to the endodermis.

\section{REFERENCES}

AMARASINGHE, V. \& WATSON, L., 1988, Comparative ultrastructure of microhairs in grasses. Bot. J. Linn. Soc., 98: 303-319.

BRANDIS, D., 1907, Remarks on the structure of bamboo leaves. Trans. Linn. Soc. Lond. Bot. Ser., 2(7): 69-92.

BUKATSCH, F., 1972, Bemerkungen zur Doppelfarbung Astrablau-Safranina. Mikrokosmos, 61: 225.

CALDERÓN, C. E. \& SODERSTROM, T. R., 1973, Morphological and anatomical considerations of the grass subfamily Bambusoideae based on the genus Maclurolyra. Smith. Contr. Bot., 11: 55.

CAMPOS, A. C. \& LABOURIAU, L. G., 1969, Corpos silicosos de gramíneas dos cerrados II. Pesq. Agropec. Bras., 4: 143-151.

CAROLIN, R. C., JACOBS, S. W. L. \& VESK, M., 1973, The structure of the cells of the mesophyll and parenchymatous bundle sheath of the Gramineae. Bot. J. Linn. Soc., 66: 259-275.

CAVAlCANTE, P. B., 1968, Contribuição ao estudo das gramíneas amazônicas. Bol. Mus. Par. Emilio Goeldi (Bot.), 30: 1-38.

CLAYTON, W. D. \& RENVOIZE, S. A., 1986, Genera Graminum. Kew Bulletin Adicional Series XIII, London, 389 p.

DAHLGREN, R. M., CLIFFORD, H. T. \& YEO, P. F., 1985, The families of the monocotyledons. Structure, evolution and taxonomy. Springer-Verlag, New York, 520p.

ELLIS, R. P., 1976, A procedure for standardizing comparative leaf anatomy in the Poaceae I: the leaf blade as viewed in transversal section. Bothalia, 12(1): 65-109.

ELLIS, R. P., 1979, A procedure for standardizing comparative leaf anatomy in the Poaceae II: the epidermis as seen in surface view. Bothalia, 12(4): 641-671.

ESAU, K., 1977, Anatomy of seed plants. Academic Press, New York, 550p.

FAHN, A., 1985, Anatomía Vegetal. Ediciones Pirámide S. A., Madrid, 599p.

FILGUEIRAS, T. S., 1988, Bambus nativos do Distrito Federal, Brasil (Gramineae:Bambusoideae). Revta Brasil. Bot., 11: 47-66. 
FISHER, D. B., 1967, An unusual layer of cells in the mesophyll of the soybean leaf. Bot. Gaz., 128(3-4): 215-218.

FONT QUER, P., 1975, Diccionario de Botanica. Labor., $1244 \mathrm{p}$.

FRANCESCHI, V. R. \& GIAQUINTA, R. T., 1983a, The paraveinal mesophyll of soybean leaves in relation to assimilate transfer and compartmentation. I Ultrastructure and histochemistry during vegetative development. Planta, 157: 411-421.

FRANCESCHI, V. R. \& GIAQUINTA, R. T., 1983b, The paraveinal mesophyll of soybean leaves in relation to assimilate transfer and compartmentation. II. Structural, metabolic and compartimental changes during reproductive growth. Planta, 157: 422-431.

FRANCESCHI, V. R. \& GIAQUINTA, R. T., 1983c Specialized cellular arrangements in legume leaves in relation to assimilate transport and compartmentation: comparison fo the paraveinal mesophyll. Planta, 159: 415-422.

FREIER, F., 1959, Las células clorenquimáticas del mesófilo de las gramíneas. Rev. Arg. Agr., 26(1-2): 1-16.

HABERLANDT, G., 1928, Physiological plant anatomy. Macmillan \& Co Ltda., London, 777p.

HOPKINS, W. G., 1995, Introduction to plant physiology. John Wiley \& Sons, New York, 464p.

JENSEN, W. A., 1962, Botanical histochemistry: principles and practice. W. H. Freeman and Company, San Francisco, 408p.

JOHANSEN, D. A., 1940, Plant microtechnique. McGrawHill Book Company Inc, New York, 523p.

JONES, L. H. P. \& HANDRECK, K. A., 1965, Studies of silica in oat plant III. Uptake of silica from soils by the plant. Plant Soil, 23: 79-96.

KARELSTSCHICOFF, S., 1868, Die faltenfoermigen verdick ungen. Bull. Soc. Imp. Nat., 41: 180-90.

LANNING, F. C., PONNAIYA, B. W. X. \& CRIMPTON, C. F., 1958, The chemical nature of silica in plants. Plant Physiol., 33(5): 339-43.

MC NAUGHTON, S. J. \& TARRANTS, J. L., 1983, Grass leaf silicification: natural selection for an inducible defense against herbivores. Proc. Nat. Acad. Sci., 80: 790-791.

METCALFE, C. R., 1956, Some thougts on the structure of bamboo leaves. Bot. Mag., 69: 391-400.

METCALFE, C. R., 1963, Comparative anatomy as a modern botanical discipline with special reference to recent advances in the systematic of monocotyledons. Adv. Bot Res., 1: 101-147.

METCALFE, C. R., 1960, Anatomy of the monocotyledons I. Gramineae. Clarendon Press, Oxford, 731p.

MOORE, D., 1984, The role of silica in protecting Italian rye grass from attack by dipterous stem-boring larvae. Ann. Appl. Biol., 104(1): 161-6.
PAGE, V. W., 1947, Leaf anatomy of Streptochaeta and the relation of this genus to the bamboos. Bull. Torr. Bot. Club, 74(3): 232-239.

PAISOOKSANTIVATANA, Y. \& POHL, R. W., 1992, Morphology, anatomy and cytology oh the genus Lithacline (Poaceae:Bambusoideae). Rev. Biol. Trop., 40: 47-72.

PORTERFIELD, J. R. W. M., 1937, Histogenesis in the bamboo with special reference to the epidermis. Bull. Torr. Bot. Club, 64(7): 421-432.

PRAT, H., 1936, La Sistématique des Graminées. Ann. Sci. Nat. Bot., Ser., 10(18): 165-257.

PRAT, H., 1932, L'epiderme des Graminées. Ètude anatomique et systematique. Ann. Sci. Nat. Bot., Ser. 10(14): 117-324.

RENVOIZE, S. A., 1985, A survey of leaf blade anatomy in grasses V. The bamboos allies. Kew Bull., 40(3): 509-535.

SASS, J. E., 1951, Botanical Microtechnique. The Iowa State College Press, Iowa, 228p.

SCATENA, V. L. \& NUNES, A. C., 1999, Anatomia foliar de Pleurothallis rupestris Lind. (Orchidaceae) dos campos rupestres do Brasil. Bol. Bot. Univ. São Paulo, 15: $35-43$.

SHIELDS, L. M., 1951, The involution mechanism in leaves of certain grasses. Phytomorphology, 1: 225-251.

SILVA, D. C., 2000, Anatomia dos órgãos vegetativos em espécies de Lagenocarpus Nees. (Cyperaceae) de campo rupestre. Tese de Doutorado, Instituto de Biociências, Universidade de São Paulo.

SODERSTROM, T. R., 1980, A new species of Lythachne (Poaceae: Bambusoideae) and remarks on its sleep movements. Brittonia, 32(4): 495-501.

SODERSTROM, T. R. \& CALDERÓN, C. E., 1979, A commentary on the bamboos (Poaceae: Bambusoideae). Biotropica, 11(3): 161-172.

SODERSTROM, T. R. \& ELLIS, R. P., 1988, The woody bamboos (Poaceae: Bambusoideae) of Sri Lanka: a morphological anatomical study. Smith. Cont. Bot., 72: 75.

SODERSTROM, T. R., ELLIS, R. P. \& JUDZIEWICZ, E. J., 1987a, The Phareae and Streptogyneae (Poaceae) of Sri Lanka: a morphological anatomical study. Smith. Cont. Bot., 65: 26 .

SODERSTROM, T. R., HILU, K. W., CAMPBELL, C. S. \& BARKWORTH, M. E., 1987b, Grass systematics and evolution. Smithsonian Institution Press, Washington, 473p.

SODERSTROM, T. R., JUDZIEWICZ, E. J. \& CLARK, L., 1988, Distribution patterns of neotropical bamboos. Proceedings of a Workshop on Neotropical Distribution Patterns. Academia Brasileira de Ciências, Rio de Janeiro, pp. 121-127.

SÖNDAHL, M. R. \& LABOURIAU, L. G., 1970, Corpos silicosos de gramíneas dos cerrados IV. Pesq. Agropec. Bras., 5: 183-207. 
TATEOKA, T., INOWE, S. \& KAWANO, K., 1959, Notes on some grasses IX: Systematic significance of bicellular microhairs of leaf epidermis. Bot. Gaz., 121(2): 80-91.

TEIXEIRA DA SILVA, S. \& LABOURIAU, L. G., 1970, Corpos silicosos de gramíneas dos cerrados III. Pesq. Agropec. Bras., 5: 167-182.

TERREL, E. E. \& WERGIN, W. P., 1979, Scanning electron microscopy and every dispersive $\mathrm{X}$ ray analysis of leaf epidermis in Zizania (Gramineae). Scan. Electr. Microsc., 3: 81-88.
TURPE, A. M., 1966, Histotaxonomía de las especies argentinas del género Paspalum. Lilloa, 32: 35-299.

WATTIEZ, N. \& STERNON, F., 1942, Elements de Chemie Vegetale. 2. ed. Masson et Cie Editeurs, Paris, 844p. 